Pomáhajúce profesie, roč. 3, č. 2, 2020, 12-22

\title{
SÚVIS STRATÉGIÍ ZVLÁDANIA ZÁŤAŽE S PRÍTOMNOSŤOU OTCA VO VÝCHOVE U ZÁVISLÝCH OD NELEGÁLNYCH DROG
}

\author{
Richard Wolt 1,2, Miroslava, Pašková1, Martina Romanová ${ }^{3}$ \\ ${ }^{1}$ Katedra psychologických vied FSVaZ UKF Nitra \\ ${ }^{2}$ Centrum pre liečbu drogových závislostí Banská Bystrica \\ 3Ústav aplikovanej psychológie FSVaZ UKF Nitra \\ rwolt@ukf.sk
}

\begin{abstract}
Abstrakt: Ciel'om výskumu bolo analyzovat' súvislosti medzi prítomnost'ou otca vo výchove a stratégiami zvládania zát’aže u závislých od nelegálnych drog. Výskumný súbor tvorilo 51 respondentov, z toho 42 mužov a 9 žien, ktorí sa liečia v zariadeniach pre liečbu drogových závislostí $(M=24,7$ rokov, $S D=6,25)$. Na zistenie prítomnosti otca vo výchove bola použitá dimenzia vzt'ah s otcom dotazníka Father presence questionnaire (FPQ), ktorý vytvorili Krampeová a Newton (2006). Za účelom zistenia preferencie stratégií zvládania zát’aže bol predkladaný skrátený dotazník stratégií zvládania zát’aže Brief COPE (Carver, 1997). Zistili sme, že vyššia miera prítomnosti otca vo výchove súvisí s tromi adaptívnymi stratégiami zvládania zát’aže (hl'adanie emocionálnej podpory, pozitívne prerámcovanie a hl'adanie inštrumentálnej podpory). Predpoklad o existencii vzt'ahu medzi nižšou mierou prítomnosti otca vo výchove s maladpatívnymi stratégiami zvládania zát'aže sa nepotrvdil. Uvedené zistenia vo výskume diskutujeme.
\end{abstract}

Kl'účové slová: stratégie zvládania zát’aže, prítomnost’ otca

\section{1 ÚVOD}

Raný vývin je dôležitou súčast’ou celkového vývinu človeka. Prostredie, v ktorom sa nachádza a vzt'ahy, ktoré nadväzuje formujú jeho správanie aj v dospelosti. Teória vzt'ahovej väzby hovorí o spôsobe, ktorým diet'a získava $\mathrm{v}$ svojom svete istotu a bezpečie, alebo naopak, neistotu a nedostatok lásky, ktoré môžu neskôr viest' k rôznym problémom v správaní. Jedným z rizikových faktorov vzniku závislosti, je napríklad aj stres. Ak je stres nadmerný a dlhodobý, môže viest' k vzniku závislosti a pri samotnej liečbe chronický stres zvyšuje riziko recidív. Pri liečbe závislostí býva vel’mi nápomocné, ak si závislí osvoja efektívne stratégie zvládania stresu (Nešpor, 2003).

Prítomnost' otca vo výchove je téma, ktorej sa v slovenskej literatúre nevenuje vel'a pozornosti. Väčšina výskumov sa venuje okolnostiam a situácii, kedy otec prítomný nie je vôbec. Podl'a Rostada (2014) psychologická prítomnost' otca dokáže predikovat' rizikové správanie, medzi ktoré patrí napríklad sexuálne správanie či užívanie drog, a tak $\mathrm{v}$ zhode $\mathrm{s}$ teóriami pripútania môže psychologická prítomnost' otca pôsobit' ako preventívny faktor.

\subsection{Stratégie zvládania zát’aže}

Zvládanie stresu, či zát'ažových situácií označujeme pojmom coping. Zvládanie zát’aže je základným prvkom k úplnému porozumeniu účinkov stresu na človeka, pretože neznázorňuje iba aktívnu úlohu jednotlivca v procese riešenia požiadaviek, ale môže ukázat’ aj vývoj tohto procesu (Skinner, Zimmer-Gembeck, 2007). Pargament (1990) vníma zvládanie zát’aže ako proces, prostredníctvom ktorého sa jednotlivci snažia porozumiet’ a vyrovnat' s významnými osobnými alebo situačnými požiadavkami v ich živote. Niektorí autori chápali zvládanie zát’aže iba ako úspešné zvládnutie 
zát’ažovej situácie, avšak podl’a novších definícií je zvládanie opisované ako úsilie jednotlivca zvládnut' situáciu bez ohl'adu na to, či je proces úspešný alebo nie (Oravcová, 2004). Ak sa človek nenachádza v žiaducom stave, snaží sa konat’ tak, aby zlepšil svoju situáciu a aby nepriaznivý stav zvládol. Spôsoby, ktorými človek tieto situácie zvláda sú rôzne. Takisto je rôzna aj efektivita jednotlivých postupov (Křivohlavý, 2001). Podl’a Oravcovej (2004) stratégie zvládanie zát’aže sú takými vzorcami správania, ktoré využívame na zvládnutie zát’ažovej situácie. Folkmanová a Lazarus (1984) rozdelili stratégie zvládania zát’aže na dve hlavné kategórie. Tie, ktoré sú zamerané na riadenie a riešenie príčiny problému (problem-focused) a tie, ktoré sa zameriavajú na reguláciu emočnej odpovede na problém (emotion-focused). Vel'mi rozsiahle delenie používa Carver Scheier a Weintraub (1989), ktorí vymedzili celkom až trinást' stratégií zvládania zát'aže:

- Aktívne zvládanie zátaže - je zamerané na podnikanie konkrétnych krokov, ktoré sa snažia odstránit' stresor alebo zmiernit' jeho účinky.

- Plánovanie - je uvažovanie o tom, akým spôsobom je možné vysporiadat' sa s daným stresorom. Zahŕňa tvorenie stratégií a premýšl’anie o krokoch, ktoré umožnia problém čo najlepšie zvládnut'.

- Pozitívne prerámcovanie - zamerané na zvládnutie úzkostných emócií, vedie človeka $\mathrm{k}$ tomu, aby pokračoval v aktívnom zvládaní problému.

- $\quad$ Akceptácia - prijatie reality, stresovej situácie, ktorá vedie k vyrovnaniu sa s ňou.

- Humor.

- Náboženstvo - tendencia obrátit’ sa na náboženstvo v čase pôsobenia stresoru. Môže sa stat' zdrojom emocionálnej podpory, prostriedkom pre pozitívne prerámcovanie, či taktikou aktívneho zvládania stresoru.

- Hladanie inštrumentálnej podpory - hl'adanie rady, pomoci či informácií.

- Hladanie emocionálnej podpory - morálna podpora, súcit a porozumenie.

- Sebarozptýlenie - odvracia pozornost' človeka od premýšl’ania nad správaním, ktoré súvisí s dosiahnutím ciel'a, ktorý je zasiahnutý stresorom,

- Sústredenie sa na emócie a ich ventilácia - tendencia sústredit' sa na akékol'vek utrpenie, či ventilácia týchto pocitov.

- Odangažované správanie - vzdanie sa pokusu o dosiahnutie ciel’ov, ktoré stresor zasahuje. Tak znižuje námahu, ktorou je potrebné vysporiadat' sa so stresorom.

- Sebaobviňovanie - kritika seba samého, obviňovanie sa z vecí, ktoré sa stali.

- Popieranie - odmietnutie viery v to, že stresor existuje, či správanie sa tak, ako by

- stresor neexistoval.

- Užívanie návykových látok.

Mnohé výskumy (Belding, et. al. 1996; Hyman et. al. 2009; Adan, Antúnez, Navarro, 2017) poukazujú na súvislost' častejšieho využívania maladaptívnych stratégií, či menej častého používania adaptívnych stratégií zvládania vo vzt’ahu s užívaním návykových látok. Významným protektívnym faktorom je vzt'ah s rodičmi. V našom výskume sme sa zamerali na vzt’ah s otcom. Podl'a Brooka, Whitemana a Gordona (1985) deti, ktoré v domácnosti nemali prítomného otca, častejšie užívali drogy v porovnaní s adolescentmi, u ktorých otec prítomný bol. Iná štúdia, ktorú realizovali Bronke-Tinkew, Moore a Carrano (2006) podporila tvrdenie, že pozitívnejší vzt'ah 
medzi otcom a diet’at’om predikuje znížené rizikové správanie a je teda spojené s nižším rizikom páchania trestnej činnosti ako aj užívania návykových látok.

\subsection{Prítomnost' otca}

Prítomnost' otca je vnímaná ako psychologická prítomnost', čo predstavuje psychologickú blízkost' a dostupnost' pre diet'a (Krampe, Newton, 2006). Prítomnost' otca je akási spolupatričnost' s diet'at'om alebo lepšie povedané, opak otcovej neprítomnosti. Môžeme ju vymedzit' aj ako súlad otca s diet'at'om. Vzt'ahuje sa viac k prežívaniu u diet'at'a a nie je charakteristikou otca, či jeho správania. Prítomnost' otca sa tak môže vzt'ahovat' k zážitku diet'at'a s otcom, pričom otcom môže byt' otec biologický, nevlastný ale aj iný mužský vzor ako napríklad učitel' alebo rodinný známy. Výskum, ktorý realizovali Ball, Mossele a Pedersen (2007) preukázal súvislost' u mladých l'udí, ktorí vnímali pozitívne angažovanost' otca a používaním adaptívnych stratégií zvládania zát'aže. 0 preukázanej súvislosti medzi kvalitou rodičovského vzt’ahu a používaním stratégií zameraných na emócie hovorí aj výskum, ktorý realizovali Grossman a Rowat (1995). Výskum, ktorý sa zaoberal vzájomným vzt'ahom otca a dietata $v$ súvislosti so stratégiami zvládania zát’aže osvojenými diet'at'om preukázal, že používanie adaptívnych stratégií diet’at’om silne súvisí s blízkym vzt’ahom medzi diet'at'om a jeho otcom (Brook et. al, 2002).

Na základe viacerých výskumných zistení a preskúmania problematiky sme formulovali dve hypotézy:

H1: Predpokladáme, že existuje štatisticky významný, pozitívny vzt’ah medzi prítomnost'ou otca vo výchove a adaptívnymi stratégiami zvládania zátaže u závislých od nelegálnych drog.

H2: Predpokladáme, že existuje štatisticky významný, negatívny vzt'ah medzi prítomnost'ou otca vo výchove a maladaptívnymi stratégiami zvládania zátaže u závislých od nelegálnych drog.

\section{METÓDY}

\subsection{Výskumný súbor}

Výskumný súbor tvorilo celkom 57 respondentov. Z dôvodu chýbajúcich odpovedí na niektoré otázky sme museli 6 účastníkov vyradit' z výskumu. Počet respondentov sa zredukoval na 51. Výskumný súbor tvorilo celkom 42 mužov a 9 žien, ktorí sa liečia zo závislosti od nelegálnych drog v Centre pre liečbu drogových závislostí Banská Bystrica $(\mathrm{N}=16)$, Odbornom liečebnom ústave psychiatrickom Predná Hora $(\mathrm{N}=11)$, Resocializačnom stredisku Filis Paul Krupina $(\mathrm{N}=11)$, Resocializačnom stredisku Nádej - Reménység Vel'ké Kosihy ( $\mathrm{N}=9$ ), Resocializačnom stredisku Nelegál Nový Svet $(\mathrm{N}=4)$. Použili sme dostupný, zámerný výber. Priemerný vek respondentov bol 24,7 rokov, $\mathrm{SD}=6,25$.

\subsection{Použité metódy}

Na zist'ovanie prítomnosti otca vo výchove sme použili dotazník Father presence questionnaire (FPQ), ktorý vytvorili Krampeová a Newton (2006). Tento dotazník obsahuje 3 dimenzie: Vzt’ah s otcom, Presvedčenia o otcovi a otcovstve a Medzigeneračné rodinné vplyvy. Tieto dimenzie sú d'alej rozdelené do 10 škál a dotazník tvorí celkom 134 položiek. Vzt'ah s otcom je centrálna dimenzia dotazníka FPQ, ktorú sme sa rozhodli použit’ aj v našom výskume. Dimenzia Vzt’ah s otcom zahŕňa afektívne, behaviorálne a kognitívne/percepčné prvky, ktoré sú realizované ako city diet'at'a k otcovi, jeho fyzický vzt’ah s otcom a vnímanie otcovho zapojenia/angažovania do výchovy dospelým diet'at'om.

Na zistenie stratégií zvládania zát’aže sme použili skrátenú verziu dotazník Brief COPE (Carver, 1997). Táto obsahuje celkom 28 položiek, ktoré sú rozdelené do 14 faktorov: aktívne zvládanie 
zát'aže, plánovanie, pozitívne prerámcovanie, akceptácia, humor, náboženstvo, hl’adanie inštrumentálnej a emocionálnej podpory, sebarozptýlenie, ventilácia, odangažované správanie, sebaobviňovanie, popieranie a užívanie návykových látok. Dvojdimenzionálne delenie dotazníka Brief COPE vytvoril Meyer (2001). Možno tak rozdelit’ faktory do dvoch hlavných kategórií. Prvou sú adaptívne stratégie zvládania zátaže (hl’adanie emocionálnej podpory, pozitívne prerámcovanie, akceptácia, náboženstvo, humor, aktívne zvládanie, plánovanie, hl'adanie inštrumentálnej podpory). Druhou kategóriou sú maladaptívne stratégie zvládania zát’aže (ventilácia, popieranie, užívanie návykových látok, odangažované správanie, sebarozptýlenie, sebaobviňovanie)

\section{3 Štatistická analýza dát}

Dáta sme spracovali v štatistickom programe IBM SPSS Statistics 25.0. Na základe testov rozloženia dát sme zistili, že v našom výskumnom súbore je zachované normálne rozloženie. Vzájomné vzt’ahy sme overovali použitím Pearsonovho korelačného koeficientu.

\section{VÝSLEDKY}

Deskriptívne charakteristiky skúmaných premenných uvádzame $\mathrm{v}$ tabul'ke č.1. Z výsledkov deskriptívnej štatistiky vyplýva, že najčastejšie využívanou stratégiou zvládania zát’aže v našom výskumnom súbore je užívanie návykových látok, vel’mi často je však využívaná aj stratégia plánovanie. Stratégia, ktorú respondenti využívajú najmenej často je náboženstvo, a nízku preferenciu dosahuje aj humor.

Tabul'ka č. 1 Základné ukazovatele štatistickej deskripcie dát

\begin{tabular}{|c|c|c|c|c|c|c|c|}
\hline $\mathrm{N}=51$ & M & Mdn & SD & Šikmost' & Strmost' & Min & Max \\
\hline Prítomnost' otca & 192,76 & 192,00 & 62,49 & $-0,320$ & $-1,175$ & 87,00 & 309,00 \\
\hline Sebarozptýlenie & 5,35 & 6,00 & 1,57 & $-0,360$ & $-0,225$ & 2,00 & 8,00 \\
\hline Aktívne zvládanie & 5,53 & 6,00 & 1,38 & $-0,423$ & $-0,185$ & 2,00 & 8,00 \\
\hline Popretie & 4,82 & 5,00 & 1,72 & 0,162 & $-0,778$ & 2,00 & 8,00 \\
\hline $\begin{array}{l}\text { Užívanie návykových } \\
\text { látok }\end{array}$ & 6,47 & 7,00 & 1,57 & $-0,772$ & $-0,145$ & 2,00 & 8,00 \\
\hline $\begin{array}{l}\text { Hl'adanie } \\
\text { emocionálnej } \\
\text { podpory }\end{array}$ & 4,84 & 5,00 & 1,80 & 0,329 & $-0,672$ & 2,00 & 8,00 \\
\hline $\begin{array}{l}\text { Hl'adanie } \\
\text { inštrumentálnej } \\
\text { podpory }\end{array}$ & 4,90 & 5,00 & 1,64 & 0,078 & $-0,566$ & 2,00 & 8,00 \\
\hline $\begin{array}{l}\text { Odangažované } \\
\text { správanie }\end{array}$ & 4,82 & 5,00 & 1,37 & 0,577 & 0,038 & 3,00 & 8,00 \\
\hline Ventilácia & 5,39 & 6,00 & 1,54 & $-0,493$ & $-0,254$ & 2,00 & 8,00 \\
\hline
\end{tabular}


Pomáhajúce profesie, roč. 3, č. 2, 2020, 12-22

$\begin{array}{lccccccc}\begin{array}{l}\text { Pozitívne } \\ \text { prerámcovanie }\end{array} & 4,98 & 5,00 & 1,56 & -0,099 & -0,418 & 2,00 & 8,00 \\ \begin{array}{l}\text { Plánovanie } \\ \text { Humor }\end{array} & 6,02 & 6,00 & 1,42 & -0,471 & 0,316 & 2,00 & 8,00 \\ \text { Akceptácia } & 3,86 & 4,00 & 1,50 & 0,728 & 0,300 & 2,00 & 8,00 \\ \text { Náboženstvo } & 4,82 & 5,00 & 1,53 & -0,246 & -0,265 & 2,00 & 8,00 \\ \text { Sebaobviňovanie } & 5,75 & 3,00 & 1,91 & 0,886 & -0,226 & 2,00 & 8,00 \\ & 5,94 & 6,00 & 1,64 & -0,466 & -0,618 & 2,00 & 8,00\end{array}$

Výskumným ciel’om bolo zistit' súvislosti medzi prítomnost'ou otca vo výchove a stratégiami zvládania zát’aže u závislých od nelegálnych drog. V prvej hypotéze sme predpokladali existenciu pozitívneho vzt’ahu medzi prítomnost'ou otca vo výchove a adaptívnymi stratégiami. $V$ tabul'ke č.2 uvádzame výsledky korelačnej analýzy.

Tabul'ka č.2 Prítomnost’ otca v súvislosti s adaptívnymi stratégiami zvládania zát'aže

Prítomnost' otca vo výchove

\begin{tabular}{lll}
\hline $\mathrm{N}=51$ & $\mathrm{r}$ & $\mathrm{p}$ \\
\hline Hl'adanie emocionálnej podpory &, $274^{*}$ & 0,050 \\
Pozitívne prerámcovanie &, $393^{*}$ & 0,037 \\
Akceptácia & 0,126 & 0,257 \\
Náboženstvo & 0,077 & 0,593 \\
Humor & 0,018 & 0,901 \\
Aktívne zvládanie & $-0,050$ & 0,729 \\
Plánovanie & $-0,023$ & 0,873 \\
Hl'adanie inštrumentálnej podpory &, $337^{*}$ & 0,016 \\
\hline
\end{tabular}

Poznámka: $N$ - počet respondentov, $r$ - Pearsonov korelačný koeficient, $p$ - štatistická signifikancia, ${ }^{*} p \leq 0,05$

Výsledky korelačnej analýzy poukazujú na štatisticky významné, stredne silné vzt’ahy medzi celkovým skóre prítomnosti otca a dvomi adaptívnymi stratégiami zvládania zátaže: pozitívne prerámcovanie a hl'adanie inštrumentálnej podpory. Štatisticky signifikantný, ale slabý vzt'ah môžeme vidiet' aj pri adaptívnej stratégii hl'adanie emocionálnej podpory. Štatisticky významné vzt'ahy sme nezistili medzi prítomnost’ou otca vo výchove a adaptívnymi stratégiami zvládania: 
akceptácia, náboženstvo, humor, aktívne zvládanie a plánovanie. Z výsledkov vyplýva, že vyššia miera vnímania otcovej prítomnosti súvisí s častejším používaním pozitívneho prerámcovania a hl'adaním inštrumentálnej podpory, a čiastočne aj s hl'adaním emocionálnej podpory ako adaptívnej stratégie zvládania zát’aže. Uvedené výsledky tak podporujú nami stanovenú hypotézu H1 iba čiastočne.

Tabul'ka č.3 Prítomnost' otca vo výchove v súvislosti s maladaptívnymi stratégiami zvládania

\begin{tabular}{lcc}
\hline & \multicolumn{2}{c}{ Prítomnost’ otca vo výchove } \\
\hline $\mathrm{N}=51$ & $\mathrm{R}$ & $\mathrm{P}$ \\
\hline Ventilácia &, $291^{*}$ & 0,038 \\
Popieranie & 0,145 & 0,311 \\
Užívanie návykových látok & 0,027 & 0,850 \\
Odangažované správanie & 0,223 & 0,116 \\
Sebarozptýlenie & $-0,099$ & 0,490 \\
Sebaobviňovanie & 0,270 & 0,052 \\
\hline
\end{tabular}

Poznámka: $N$ - počet respondentov, $r$ - Pearsonov korelačný koeficient, $p$ - štatistická signifikancia,

$*-p \leq 0,05$,

V tabul'ke č.3 môžeme vidiet' štatisticky významný, ale slabý pozitívny vzt’ah medzi celkovým skóre prítomnosti otca vo výchove a ventiláciou. K štatisticky významnému výsledku sa blíži aj vztah medzi prítomnost'ou otca a sebaobviňovaním. Štatisticky významné vzt'ahy sa neprejavili medzi prítomnost'ou otca vo výchove a štyrmi maladaptívnymi stratégiami: popieranie, užívanie návykových látok, odangažované správanie a sebarozptýlenie. Z výsledkov vyplýva, že častejšie používanie maladaptívnej stratégie ventilácia a čiastočne aj sebaobviňovanie pozitívne súvisí s vyšším vnímaním otcovej prítomnosti vo výchove. Výsledky teda našu druhú hypotézu nepodporili.

\section{DISKUSIA}

Neprítomnost' otca zvyšuje rizikové správanie, medzi ktoré patrí napríklad aj užívanie drog, ale taktiež zvyšuje pravdepodobnost' výberu nepriaznivého správania, zatial' čo otcova prítomnost' poskytuje ochranu spojenú s týmito vol'bami (Farrel, White, 1998). Výskumným ciel’om bolo objasnit' súvislosti medzi prítomnost'ou otca vo výchove a stratégiami zvládania zát'aže. Výsledky výskumu čiastočne podporili hypotézu, ktorá predpokladala pozitívny vzt'ah medzi prítomnost'ou otca a adaptívnymi stratégiami zvládania zát’aže. Pozitívne vzt’ahy sme zistili medzi celkovým skóre prítomnosti otca a hl'adaním emocionálnej podpory, pozitívnym prerámcovaním a hl'adaním inštrumentálnej podpory. Druhá hypotéza nebola výsledkami podporená, zistili sme však štatisticky významný pozitívny vzt'ah medzi celkovou otcovou prítomnost'ou a maladaptívnou stratégiou ventilácia a k štatisticky významnému vzt’ahu sa blížil aj vzt’ah medzi prítomnost’ou otca a sebaobviňovaním. 


\section{Pomáhajúce profesie, roč. 3, č. 2, 2020, 12-22}

Adaptívne stratégie predstavujú zvládanie zát’ažovej situácie, ktoré smeruje k jej úspešnému zvládnutiu, čo znamená, že osoba, ktorá zažíva zát’až vynakladá úsilie na jej úspešné zvládnutie (Zelina, Zelinová, 2009). Hl'adanie inštrumentálnej podpory síce patrí k stratégiám, ktoré sú zamerané na riešenie problému, avšak tak ako aj hl'adanie emocionálnej podpory, formulácia výrokov v dotazníku sa jasne týka sociálnej podpory (Dostal/a som pomoc a radu od iných l'udí) a teda je prirodzené, že ak má diet’a vyššiu kvalitu vzt’ahu s otcom, o ktorej hovorí aj premenná prítomnost' otca, obráti sa s hl'adaním podpory či už inštrumentálnej alebo emocionálnej práve na neho. Tieto zistenia podporujú aj výsledky výskumu, kde adolescenti uvádzajú, že najväčším zdrojom emocionálnej a inštrumentálnej podpory sú práve rodičia a za nimi nasledujú rovesníci (Trask, et al. 2002). Shulman, Collins a Dital (1993) uvádzajú, že hoci vzt’ah medzi diet’at'om a rodičom prechádza zmenou a zvyšuje sa význam blízkych priatel'stiev s rovesníkmi, rodičia zostávajú stále dôležitým zdrojom podpory pre adolescenta. Súvislost' vo vzt'ahu k adaptívnym stratégiám, ktorú sa nám nepodarilo plne preukázat', môže byt' vysvetlená viacerými faktormi. Jedným z faktorov, ktoré mohli mat' vplyv na nepreukázanie vzt'ahu medzi adaptívnymi stratégiami a prítomnost'ou otca je, že $\mathrm{v}$ procese liečby drogovej závislosti dochádza k zmenám v používaní stratégií zvládania zát’aže. Dochádza najmä k zvyšovaniu využívania aktívneho zvládania. Boden so spolupracovníkmi (2014) uvádza nárast aktívneho zvládania a pokles používania maladaptívnych stratégií u liečiacich sa závislých. Plánovanie bolo v našom výskumnom súbore druhou najčastejšie používanou stratégiou zvládania. Zameriava sa na premýšl'anie o tom, aké kroky možno pri riešení problému vykonat'. Plánovanie však nemá podl'a Litmana (2006) spojitost' so sociálnou interakciou, čo môže byt' dôvodom, prečo sme nenašli spojitost' medzi vyššou úrovňou otcovej prítomnosti a danou adaptívnou stratégiou zvládania. Humor a náboženstvo dosahovali najnižšie skóre vo výskumnom súbore, teda tieto dve stratégie sú našimi respondentami aj najmenej používané. Celkové minimálne používanie týchto stratégií tak môže vysvetl'ovat' aj ich štatisticky nevýznamný vzt'ah s otcovou prítomnost’ou. Domnievame sa, že vel'kú rolu pri nezistení vzt'ahu medzi humorom, náboženstvom a akceptáciou mohol zohrat' fakt, že tieto stratégie sa vel'akrát vyskytujú vo výskumoch ako nezaradené. A teda, že humor, náboženstvo ani akceptácia sa nepovažuje vždy za adaptívnu stratégiu ale v niektorých prípadoch ich autori zarad'ujú medzi stratégie maladaptívne. Vašina (1999) uvádza, že je potrebné prihliadat' na individuálnu životnú situáciu každého jednotlivca, aby bolo možné identifikovat', či sa jedná o efektívny alebo neefektívny spôsob zvládania. U závislých býva humor často používaný ako spôsob zl'ahčovania svojej situácie, odvádzania pozornosti od plného uvedomenia si dôsledkov svojej závislosti a dopadu na rodinu a iné aspekty života. Domnievame sa, že nepreukázanie súvislostí medzi viacerými adaptívnymi stratégiami zvládania zát’aže môže byt' spojené aj s tým, že matky môžu byt' pre deti vplyvnejším vzorom vo vytváraní a používaní stratégií zvládania zát’aže, ako otcovia. Tento predpoklad podporuje aj výskum, ktorý realizoval Monti so spolupracovníkmi (2017), v ktorom stratégie zvládania matky pozitívne korelovali so stratégiami zvládania detí, zatial' čo pri stratégiách zvládania zát'aže otcov a ich detí táto súvislost' preukázaná nebola.

Čo sa týka vzt’ahu maladaptívnych stratégií s otcovou prítomnost’ou, náš výskum priniesol zaujímavé zistenie, ktoré hovorí o pozitívnom vzt’ahu ventilácie $\mathrm{s}$ vyššou úrovňou otcovej prítomnosti. Viacerí autori (Brown, Westbrook, Challagalla, 2005; Carver, 1997; Carver, Scheier, Weintraub, 1989) považujú túto stratégiu za maladaptívnu. Ciel’om ventilácie je získat' úl'avu od negatívnych pocitov, napríklad prostredníctvom hlasového prejavu. Zameranie sa na negatívne udalosti a následne negatívne emócie však odvádzajú pozornost' od aktivít, ktoré sú užitočné pre dosiahnutie ciel’ov. Naopak Bosson (2006) na základe výsledkov svojho výskumu uvádza, že pre posilnenie interpersonálnych vzt’ahov je vel’mi prínosné prejavovanie negatívnych emócií. Ventiláciu vníma ako vel’mi účinný prostriedok pri zvládaní zát’ažových situácií. Zdiel'anie negatívnych emócií je pravdepodobne vel’mi žiadúce, pretože vytvára hranice v skupine, v ktorej 
sú emócie zdiel'ané, zvyšuje sebaúctu, a navyše poskytuje podrobné informácie o tých, ktorí svoje postoje a emócie prezentujú. Liečba závislostí je postavená najmä na skupinovej terapii, v rámci ktorej sa závislí v liečebnom procese učia zdiel’at' svoje prežívanie, porozumiet' svojim emóciám, ktoré boli predtým potláčané užívaním návykových látok. U mnohých sa na začiatku objavujú v prežívaní negatívne emócie, ktoré súvisia s uvedomovaním si dôsledkov svojej situácie (Kalina, Miovský, 2008). Výsledky nášho výskumu sa blížia $\mathrm{k}$ hranici štatistickej významnosti v prípade vzt'ahu medzi otcovou prítomnost'ou a používaním sebaobviňovania ako maladaptívnej stratégie. Prekvapivo smer tohto vzt’ahu sa ukazuje tiež ako pozitívny. Výsledky výskumu realizovaného na det'och, ktoré boli zneužívané ukazujú, že blízkost' vzt'ahu s páchatel'om pozitívne koreluje so sebaobviňovaním. Vyššia miera viny, ktorú človek pocit’uje je spôsobená vytvorenou dôverou a blízkym vzt’ahom a tak obracia vinu proti sebe samému. (Quas, Goodman, Jones, 2003). V rámci liečby závislostí sa závislí učia ventilovat' svoje prežívanie zdravším spôsobom. V minulosti sa naučili používat' na zmiernenie negatívneho emočného rozpoloženia návykové látky, ktoré tlmili ich emócie. Aj výsledky v našom výskumnom súbore poukazujú na to, že užívanie návykových látok je najfrekventovanejšou stratégiou zvládania zát'aže. Dížka liečebného procesu však nemusí postačovat' pre osvojenie si adaptívnych stratégií. Čo sa týka maladaptívnych stratégií ako popieranie, užívanie návykových látok, odangažované správanie a sebarozptýlenie, ani jedna z nich nevyžaduje sociálnu interakciu. Otcovské správanie môže mat' teda menší vplyv práve na tieto stratégie, ako napríklad na hl'adanie inštrumentálnej, či emocionálnej podpory práve kvôli tomu, že je menšia pravdepodobnost' prepojenia týchto stratégií so sociálnou interakciou (Smith, et. al. 2006).

\section{LIMITY A ZÁVER}

Napriek výsledkom našej analýzy, ktorá naznačuje zaujímavé zistenia si uvedomujeme, že práca má viaceré limity a tak sme vel'mi opatrní pri zovšeobecňovaní interpretácí́. Prvým z nich je nepomer rozloženia mužov a žien vo výskumnom súbore. Ďalším limitom našej práce sú aj chýbajúce údaje spojené so zist’ovaním rôznych iných aspektov otcovstva, napr. informácia o spolužití respektíve nespolužití s otcom v jednej domácnosti, rodinný stav rodičov, či smrt' otca. Stanovený ciel' výskumu sa nám podarilo naplnit’ a prepojit' do vzájomného vzt'ahu dve premenné -stratégie zvládania zát’aže s prítomnost'ou otca vo výchove. Štatistická analýza preukázala čiastočné podporenie nami stanovenej hypotézy. Osvojenie si adaptívnych stratégií zvládania čiastočne súvisí s prítomnost'ou otca vo výchove, čím sme rozšírili spektrum poznatkov o význame vzt’ahovej väzby a vzt'ahového správania v súbore závislých od nelegálnych drog.

\section{LITERATÚRA}

Adan, A., Antúnez, J. M., Navarro, J. F. (2017). Coping strategies related to treatment in substance use disorder patients with and without comorbid depression. Psychiatry Research, 251, 325-332. Ball, J., Moselle, K., Pedersen, S. (2007). Father's Involvement as a Determinant of Child Health [online]. Canada: National Responsible Fatherhood Clearinghouse, 36 p. [cit. 2020-04-20]. Dostupné na http://www.ecdip.org/docs/pdf/PH\%20FI\%20Final\%20Full\%20Report.pdf

Belding, M. A., Iguchi, M. Y., Lamb, R. J., Lakin, M., Terry, R. (1996). Coping strategies and continued drug use among methadone maintenance patients. Addictive behaviors, 21(3), 389-401.

Boden, M. T., Kimerling, R., Kulkarni, M., Bonn-Miller, M. O., Weaver, C., Trafton, J. (2014). Coping among military veterans with PTSD in substance use disorder treatment. Journal of substance abuse treatment, 47(2), 160-167. 
Bosson, J. K., Johnson, A. B., Niederhoffer, K., Swann Jr, W. B. (2006). Interpersonal chemistry through negativity: Bonding by sharing negative attitudes about others. Personal Relationships, 13(2), 135-150.

Bronte-Tinkew, J., Moore, K. A., Carrano, J. (2006). The Father-Child Relationship, Parenting Styles, and Adolescent Risk Behaviors in Intact Families. Journal of Family Issues, 27(6), 850-881.

Brook, J. S., Whiteman, M., Gordona, A. S. (1985). Father absence, perceived family characteristics and stage of drug use in adolescence. British Journal of Developmental Psychology, 3 (1), 87-94.

Brook, D. W., Brook, J. S., Whiteman, M., Arencibia-Mireles, O., Pressman, M. A., Rubenstone, E. (2002). Coping in adolescent children of HIV-positive and HIV-negative substance-abusing fathers. The Journal of genetic psychology, 163(1), 5-23.

Brown, S. P., Westbrook, R. A., Challagalla, G. (2005). Good cope, bad cope: adaptive and maladaptive coping strategies following a critical negative work event. Journal of applied psychology, 90(4), 792-798.

Carver, CH. S. (1997). You want to measure coping but your protocol'too long: Consider the brief cope. International journal of behavioral medicine, 4(1), 92-100

Carver, CH. S., Scheier, M. F., Weintraub, J. K. (1989). Assessing coping strategies: a theoretically based approach. Journal of personality and social psychology, 56(2), 267-283.

Farrel, A.B., White, K.S.(1998). Peer Influences and Drug Use Among Urban Adolescents: Family Structure and Parent-Adolescent Relationship as Protective Factors, Journal of Consulting and Clinical Psychology, 6(2), 248-58.

Folkman, S., Lazarus, R. S. (1980). An analysis of coping in a middle-aged community sample. Journal of health and social behavior, 21(3), 219-239.

Grossman, M., Rowat, K. M. (1995). Parental relationships, coping strategies, received support, and well-being in adolescents of separated or divorced and married parents. Research in Nursing \& Health, 18(3), 249-261.

Hyman, S. M., Hong, K. I. A., Chaplin, T. M., Dabre, Z., Comegys, A. D., Kimmerling, A., Sinha, R. (2009). A stress-coping profile of opioid dependent individuals entering naltrexone treatment: A comparison with healthy controls. Psychology of Addictive Behaviors, 23(4), 613.

Kalina, K., Miovský, M. Psychoterapie v léčbě závislostí (2008). In: Kalina, K. a kol.: Základy klinické adiktologie. 1. vyd. Praha: Grada Publishing. 159 s.

Krampe, E.M., Newton, R. R. (2006). The Father Presence Questionnaire: A New Measure of the Subjective Experience of Being Fathered. Fathering, 4(2), 159-190.

Křivohlavý, J. (2001). Psychologie zdraví. Praha: Portál. 279 s.

Litman, J.A. (2006). The COPE inventory: Dimensionality and relationships with approach-and avoidance-motives and positive and negative traits. Personality and Individual differences, 41(2), 273-284.

Meyer, B. (2001). Coping with Severe Mental Illness: Relations of the Brief COPE with Symptoms, Functioning, and Well-Being. Journal of Psychopathology and Behavioral Assessment, 23(4), 265 277. 
Monti, J. D., Winning, A., Watson, K. H., Williams, E. K., Gerhardt, C. A., Compas, B. E., Vannatta, K. (2017). Maternal and paternal influences on children's coping with cancer-related stress. Journal of child and family studies, 26(7), 2016-2025.

Nešpor, K. (2003). Alkohol, jiné látkové závislosti a stres. Alkoholizmus a drogové závislosti (Protialkoholický obzor), 38(2), 155-160.

Oravcová, J. (2004). Sociálna psychológia. Banská Bystrica: UMB v Banskej Bystrici. 314 s.

Pargament, K. I. et al. (1990). God help me:(I): Religious coping efforts as predictors of the outcomes to significant negative life events. American journal of community psychology, 18(6), 793-824.

Quas, A., Goodman, G. S., Jones, D. P. (2003). Predictors of attributions of self-blame and internalizing behavior problems in sexually abused children. Journal of Child Psychology and Psychiatry, 44 (5), 723-736.

Rostad, W. L., Silverman, P., McDonnald, M. K (2014). Daddy's Little Girl Goes to College: An Investigation of Females' Perceived Closeness With Fathers and Later Risky Behaviors. Journal of American College Health. 62(4), 213-220.

Shulman, S., Collins, W. A., Dital, M. (1993). Parent-child relationships and peerperceived competence during middle childhood and preadolescence in Israel. The Journal of Early Adolescence, 13(2), 204-218.

Skinner, E. A., Zimmer-Gembeck, M. J.(2007). The development of coping. Annual Review of Psychology, 58, 119-144.

Smith, C. L., Eisenberg, N., Spinrad, T. L., Chassin, L., Morris, A. S., Kupfer, A., ... Kwok, O. M. (2006). Children's coping strategies and coping efficacy: Relations to parent socialization, child adjustment, and familial alcoholism. Development and Psychopathology, 18(2), 445-469.

Trask, C. et al. (2002). Parent and adolescent adjustment to pediatric cancer: Associations with coping, social support, and family function. Journal of pediatric oncology nursing, 20(1), 36-47.

Vašina, B. (1999). Psychologie zdraví. Ostrava: Ostravská Univerzita. 92 s.

Zelina, M., Zelinová, M. (2009). Psychológia: sociálna psychológia pre pedagogické a sociálne akadémie, pedagogické a kultúrne akadémie a stredné pedagogické školy. Bratislava : Slovenské pedagogické nakladatel'stvo.158 s.

\section{COPING STRATEGIES IN RELATION TO FATHER PRESENCE IN ADDICTED INDIVIDUALS}

Abstract: The aim of the submitted research was to analyze the relationship between father's presence and coping strategies in addicted individuals. The research sample consisted of 51 respondents, 42 men and 9 women, who were receiving substance abuse treatment in several inpatient drug rehab centers ( $M=24.7$ years, $S D=6.25)$. To identify father's presence we used The Father presence questionnaire developed by Krampe and Newton (2006). To identify preferred coping strategies, we used the short form of Brief COPE (Carver, 1997). We found out that higher level of father's presence perception is associated with three adaptive coping strategies (search for 
Pomáhajúce profesie, roč. 3, č. 2, 2020, 12-22

instrumental and emotional support, positive reframing). The hypothesis related to the relationship between lower level of father's presence and maladaptive coping strategies was not confirmed.

Key words: coping, father's presence 